Original Research Paper

\title{
Pemanfaatan Limbah Botol Plastik dalam Teknik Budidaya Hidroponik dan Vertikultur Untuk Pengembangan Rumah Pangan Lestari di Desa Montong Betok Kabupaten Lombok Timur
}

\author{
Muhammad Anwar Hadi ${ }^{1}$, Baiq Riza Tania ${ }^{2}$, Muh. Fikri ${ }^{3}$, Saripati ${ }^{4}$, Winda Novita Sari ${ }^{4}$, Ahmad Raksun ${ }^{5}$ \\ ${ }^{I}$ Program Studi Kehutanan, Universitas Mataram, Lombok, Indonesia; \\ ${ }^{2}$ Program Studi Hubungan Internasional, Universitas Mataram, Lombok, Indonesia; \\ 3 Program Studi Agroekoteknologi, Universitas Mataram, Lombok, Indonesia; \\ 4 Program Studi Ilmu dan Teknologi Pangan, Universitas Mataram, Lombok, Indonesia; \\ 5 Program Studi Pendidikan Biologi, FKIP, Universitas Mataram, Lombok, Indonesia;
}

https://doi.org/10.29303/jpmpi.v3i2.657

Sitasi: Hadi, M. A., Tania, B. R., Fikri, M., Saripati, Sari, W. N., \& Raksun, A. (2021). Pemanfaatan Limbah Botol Plastik dalam Teknik Budidaya Hidroponik dan Vertikultur Untuk Pengembangan Rumah Pangan Lestari di Desa Montong Betok Kabupaten Lombok Timur. Jurnal Pengabdian Magister Pendidikan IPA, 4(2)

Article history

Received: 05 Januari 2021

Revised: 19 Februari 2020

Accepted: 05 Maret 2021

*Corresponding Author: Muhammad Anwar Hadi, Program Studi Kehutanan, Universitas Mataram, Lombok, Indonesia;

Email:

ahmadunram@unram.ac.id

\begin{abstract}
Pandemi covid-19 mempengaruhi kondisi kehidupan masyarakat, salah satunya sektor pangan. Salah satu alternatif untuk mengatasi masalah tersebut adalah dengan menerapkan konsep rumah pangan lestari dengan memanfaatkan botol plastik sebagai media untuk teknik budidaya vertikultur dan hydroponik. Kegiatan ini diharapkan dapat membantu memenuhi kekurangan ketersediaan pangan dan sekaligus mengatasi limbah plastik di lingkungan masyarakat. Metode dalam menerapkan konsep rumah pangan lestari dengan teknik vertikultur dan hidroponik yaitu dengan sosialisasi dan pengaplikasian secara langsung di SMAN 1 Montong Gading dan kantor Desa Montong Betok serta dilakukan evaluasi dengan kuisioner. Hasil kegiatan ini yaitu terbentuknya contoh penerapan rumah pangan lestari di Lingkungan Kantor Desa Montontong Betok serta meningkatnya pengetahuan dan motivasi masyarakat dalam memanfaaatkan pekarangan rumah.untuk ditanami berbagai jenis komoditi pertanian seperti taman sayur sayuran
\end{abstract}

Keywords: Limbah botol plastic; Vertikultur; Hidroponik Rumah pangan lestari

kebutuhan pokok. Berbagai langkah telah dilakukan Pemerintah Indonesia untuk dapat memenuhi ketersediaan pangan masyarakat diantaranya adalah pemberian bantuan sosial dengan berbagai bentuk. Pemberian bantuan sosial bukan hanya satu satunya langkah yang dapat di tempuh untuk memenuhi ketersediaan pangan masyarakat.

Nurwati, dkk (2015) menerangkan bahwa pemberdayaan pekarangan sempit bisa dijadikan sebagai salaah satu alternatif menangkal kerawanan pangan dalam keluarga. Pemanfaatan pekarangan sempit dianjurkan menggunakan sistem vertikultur dan tanaman yang direkomendasikan adalah tanaman sayuran. 
Rumah pangan lestari (RPL) merupakan bentuk pemberdayaan pekarangan sempit di pekarangan Masyarakat. Yang dijalankan dengan berbagai teknik budidaya diantaranya adalah teknik hydroponik atau dengan vertikultur.

Hydroponik adalah budidaya tanaman dengan memanfaatkan air sebagai media tumbuhnya dengan menekankan pada pemenuhan kebutuhan nutrisi tanaman. Aplikasi nutrisi dengan menggunakan ukuran satuan part per million (ppm) yang diberikan ke tanaman mulai dari pindah tanam sampai dengan panen (BPTP, 2020).

Vertikultur adalah teknik bercocok tanam di lahan sempit dengan memanfaatkan bidang vertikal sebagai tempat bercocok tanam yang dilakukan secara bertingkat. (BPTP, 2020).

Kedua Teknik budidaya tanaman tersebut dapat diterapkan dengan barang barang bekas dan tidak memerlukan lahan yan luas dan cocok dikembangkan di pekarangan masyarakat.

Prinsip dasar KRPL adalah:

pemanfaatan pekarangan yang ramah lingkungan dan dirancang untuk ketahanan dan kemandirian pangan, (2) diversifikasi pangan berbasis sumber daya lokal, (3) konservasi sumber daya genetik pangan (tanaman, ternak, ikan), dan (4) menjaga kelestariannya melalui kebun bibit desa menuju peningkatan pendapatan dan kesejahteraan.

Penerapan konsep Rumah Pangan Lestari (RPL) di masyarakat dapat dimulai dari satuan wilayah tingkat Desa dengan memberikan pengetahuan kepada masyarakat desa tentang cara memanfaatkan lahan pekarangan rumah untuk ditanamai berbagai jenis tanaman pertanian seperti sayuran pada khusunya yang dapat dipanen dalam jangka waktu yang relatif lebih cepat. Sehingga dapat membantu memenuhi kekurangan ketersediaan pangan masyarakat selama pandemi.

Desa Montong Betok dengan sebagain besar masyarakatnya yang berpropesi sebagai petani merupakan tempat yang tepat untuk mencoba menerapkan konsep Rumah Pangan Lestari (RPL). Selain itu diharapkan melalui adanya penerapan konsep rumah Pangan Lestari di Desa Motong Betok akan dapat mengatasi masalah sampah yang saat ini menjadi masalah yang cukup serius.

Salah satu jenis sampah yang dapat dikerasikan dengan konsep RPL adalah jenis botol plastik. Botol plastik dapat dikreasikan menjadi wadah atau media dalam mengembangkan salah satu bentuk Konsep RPL yaitu Hidroponik dan Vertikultur dalam penanaman sayuran. Sehingga dengan adanya kreasi ini akan memberikan pengetahuan kepada masyarakat tentang bagaimana cara memanfaatkan sampah plastik untuk pertanian di pekarangan rumah.

\section{Metode}

Metode yang digunakan adalah sosialisasi yang bertujuan untuk meningkatkan pengetahuan masyarakat dalam memanfaatkan pekarangan rumah dengan teknik vertikultur dan hidroponik.

Pelaksanaan kegiatan sosialisasi ini dilakukan di dua tempat yaitu: (1) Sekolah menengah atas yang ada di Desa Montong betok yaitu SMAN 1 Montong Gading, dan (2) di lingkungan kantor desa Montong Betok. Sosialisasi yang dilakukan di sekolah menengah atas tersebut bertujuan agar generasi muda dapat menjadi pelopor pengembangaan rumah pangan lestari (RPL) yang bisa diterapkan di rumah masingmasing. Sosialiasasi pada sekolah menengah atas disampaikan dengan menggunakan materi presentasi dan sekaligus demonstrasi pembuatan sistem hidroponik dan vertikultur. Sosialisasi yang dilakukan di lingkungan kantor desa Montong Betok sasarannya adalah masyarakat desa yang berada disekitar kantor desa. Sosialisasi ini dilakukan dengan mengajak dan menjelaskan langsung kepada masyarakat yang datang ke kantor desa tentang bagaimana cara penerapan metode hidroponik dan vertikultur sambil menunjukkan contoh penerapan yang telah dilakukan.

Teknik analisis data yang digunakan adalah evaluasi. Evaluasi kegiatan untuk mengetahui peningkatan pengetahuan masyarakat terkait dengan pemanfaatan limbah botol plastik sebagai media hydroponik dan vertikultur dalam penerapan rumah pangan lestari yang dilakukan dengan kuisioner sebelum dan sesudah sosialisasi

\section{Hasil dan Pembahasan}

Rumah Pangan Lestari (RPL) adalah rumah penduduk yang mengusahakan pekarangan secara intensif untuk dimanfaatkan dengan berbagai sumber daya lokal secara bijaksana yang menjamin kesinambungan penyediaan lahan pangan rumah 
tangga yang berkualitas dan beragam. (Badan Litbang Pertanian, 2019).

Pelaksanaan KKN Tematik program rumah pangan lestari ini dilaksanakan sejak 11 januari 2021 sampai degnan 26 februari 2021 dengan total 45 hari. Pelaksanaan program kegiatan menggunakan teknik hidroponik dan vertikultur dengan memanfaatkan sampah plastik sebagai media atau wadah penanamannya.

Pengaplikasian limbah botol plastik sebagai media hydroponik dan vertikultur dalam penerapan rumah pangan lestari merupakan program keja KKN Tematik mahasiswa unram yang berada di Desa Montong Betok. Tujuan kegiatan ini adalah untuk memberikan motivasi kepada masyarakat sehingga masyarakat tergerak mengembangkan konsep RPL demgan memanfaatkan sampah plastik seperti botol bekas. Pelaksanaan pengaplikasian RPL dengan memanfaatkan botol plastik ini dilakukan di Desa Montong Betok, Kecamatan Montong Gading tepatnya di lahan milik desa.. Sasaran dan pelaksanaan kegiatan ini adalah masyarakat Desa Montong Betok yang berada disekitar kantor desa dan generasi mudah yang masih menempuh pendidikan sekolah menengah atas yang terletak di Desa Montong Betok

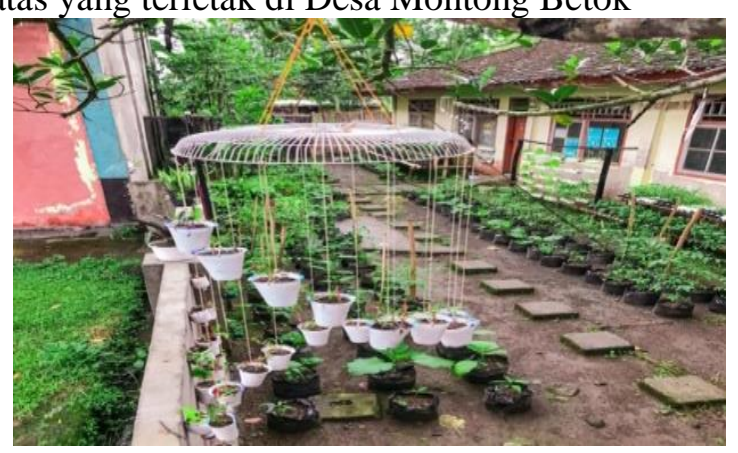

Gambar 1. Penerapan RPL di Desa Montong Betok

Langkah pertama yang ditempuh dalam menjalankan program kerja yaitu meminta izin kepada pihak desa untuk dapat menjalankan program yang dimaksud di Desa Montong Betok. Sekaligus survey awal lokasi yang akan digunakan.

Tahap awal pelaksanaan rumah pangan lestari dimulai dari pembuatan rumah bibit yang akan digunakan sebagai tempat persemaian benih baik dengan sistem hidroponik maupun sistem vertikultur sehingga dapat menyuplai kebutuhan bibit selama kegiatan.

Pembuatan sistem vertikultur dimulai dengan mempersiapkan alat dan bahan seperti: botol plastik, cutter, solder, tali, terai semai , tanah (yang sudah dicampur dengan pupuk kompos dan sekam), dan benih. Adapun Prosedur menanam dengan vertikultur yaitu: (1) buatlah terlebih dahulu media vertikulturnya melalui proses : (a) siapkan botol plastik, (b) potonglah botol plastik menjadi 2 bagian, (c) lubangi botol plastik dibagian bawah untuk jalur keluar air dengan solder dan juga jangan lupa untuk melubangi pinggir botol sebagai tempat memasukkan tali, (d) rakitlah botol plastik yang sudah dipotong, dengan tali dan disusun vertikal atau pararel, (e) masukkan media tanam (tanah yang sudah dicampur dengan pupuk kompos dan sekam) kedalam media vertikultur. (2) langkah penyemaian dan pindah tanam prosedurnya adalah: (a) siapkan terai semai yang sebelumnya sudah diisi dengan media tanam dari campuran tanah, pupuk kompos, dan juga sekam, (b) taruhlah benih disetiap lubang tanam pada pot trai, (c) siramlah benih yang sudah ditanam setiap pagi dan sore hari selama 10 - 14 Hari untuk menjaga kelembaban, (d) pindahkan benih yang sudah berumur10-14 hari atau yang sudah berdaun 4 ke media vertikultur yang sudah dibuat sebelumnya, (e) siramlah bibit yang sudah dipindahkan setiap pagi dan sore hari, (f) taruhlah media ditempat yang cukup sinar matahari, (g) lakukan perawatan, apabila ada gulma berishkanlah, (h) untuk tanaman jenis sayuran sudah dapat dipanen 25-30 hari setelah tanam

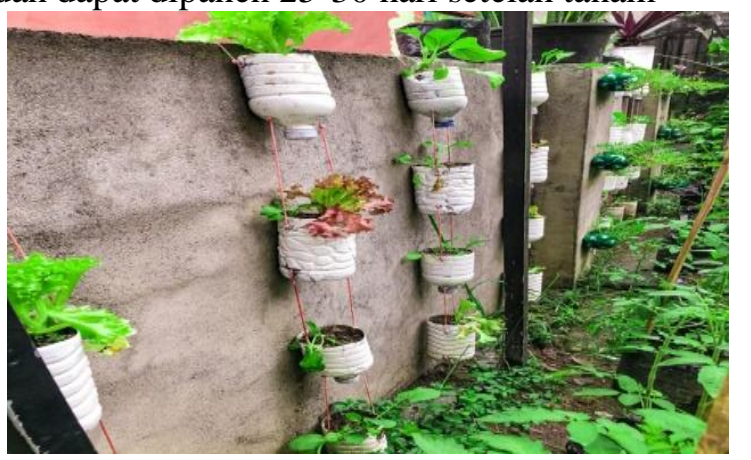

Gambar 2. vertikultur botol blastik

Pembuatan sistem hydroponik dimulai dengan mempersiapkan alat dan bahan yang akan digunakan yaitu: botol plastik, cutter, solder, cat, rockwool, TDS meter, wadah, air, benih, Nutrisi AB Mix. Adapun Prosedur menanam dengan hidroponik: (1) pembuatan instalasi hidroponik, prosedurnya adalah: (a) siapkan botol plastik, (b) lubangi botol plastik dengan solder atau pisau mengikuti diameter gelas plastik,(c) cat botol plastik dengan warna hitam untuk mencegah 
tumbuhnya lumut (d) lubangi gelas plastik dibagian bawah sebagai jalur masuknya air atau nutrisi ke tanaman, (e) apabila ingin dikreasikan seperti penyusunan instalasi yang lebih menarik dapat dilakukan sesuai dengan kreasi adapun contoh kreasi yang dilakukan adalah dengan menggantung media hidroponik pada bambu . (2) penyemaian, langkah penyemaian adalah: (a) siapkan bahan bahan yang dibutuhkan, (b) siapkan rockwool dan lubangi bagian tengahnya (c) masukkan benih sayuran kedalam lubang yang telah dibuat, (d) siram dengan air dan usahakan rockwool tetap lembab, (e) tambahkan air apabila rockwool kurang lembab, (f) pindahkan bibit apabila sudah berumur 10-14 hari atau bibit sudah berdaun 4 ke dalam media hidroponik yang sudah diisikan nutrisi. (3) pemberian nutrisi, langkah langkah: (a) siapkan nutrisi AB Mix, (b) siapkan bak yang sudah berisi air, (c) campurkan nutrisi $\mathrm{AB}$ mix dengan air sampai dengan kadar PPM yang dibutuhhkan oleh tanaman, (d) untuk mengetahui kadar PPM dapat dilakukan dengan menggukan alat TDS meter.

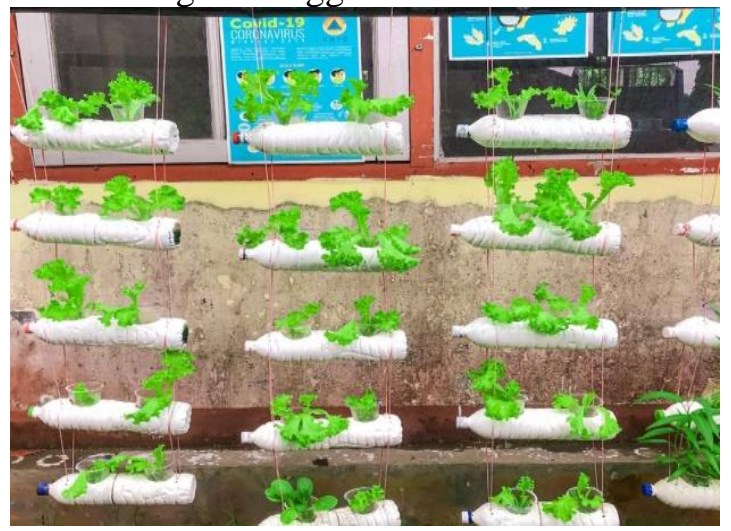

Gambar 3. sistem hydroponik botol bekas

Pelaksanaan kegiatan sosialisasi tahap 1 dilakukan di SMA Negeri 1 Montong Gading. Dalam kegiatan sosialisasi ini dihadiri oleh perwakilan siswa sebanyak 15 orang. Kemudian sosialisasi yang kedua dilakukan secara langsung dilokasi penerapan RPL dengan mengajak masyarakat yang datang ke kantor desa untuk menyaksikan contoh penerapan RPL dan menjelaskan prosedur pelaksanaanya. Selain mengajak masyarakat ada juga masyarakat yang datang secara langsung untuk melihat lihat kelokasi dikarenakn tertarik dan menanyakan langsung prosedur penanama pelaksanaan RPL dengan metode hydroponik dan vertikultur. Kedua Kegiatan sosialisasi ini bertujuan untuk meningkatkan pengetahuan dan motivasi masyarakat untuk menjalankan kegiatan RPL di pekarangan rumah.

Semua kegiatan pengaplikasian limbah botol plastik sebagai media hidroponik dan vertikultur dalam penerapan rumah pangan lestari (rpl) secara umum berjalan dengan lancar dan masyarakat pun memahami cara penerapannya.

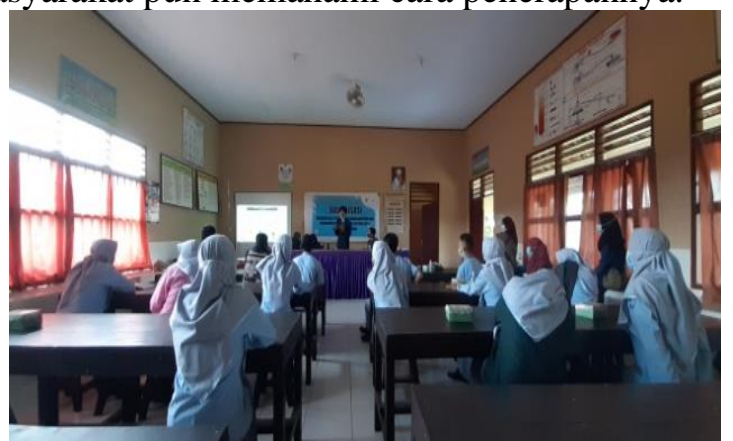

Gambar 4. Sosialisasi Penerapan RPL

Kendala kendala yang dihadapi selama pelaksanaan kegiatan ini sebagian besar dikarenakan cuaca. Cuaca yang sering tidak bersahabat seperti hujan lebat menyebabkan tanaman yang berada di sistem vertikultur mengalami pembusukan batang. Selain itu masalah yang dihadapi untuk sistem hydroponik adalah tumbuhnya lumut sehingga menyebabkan nutrisi yang diperoleh tanaman tdk terlalu maksimal

\section{Kesimpulan}

Pengaplikasian limbah botol plastik sebagai media hydroponik dan vertikultur dalam penerapan rumah pangan lestari (rpl) Di desa montong betok, kecamatan montong gading merupakan sebuah langkah yang ditempuh untuk membantu ketersediaan pangan masyarakat dan mengurangi jumlah sampah plastik (botol plastik). Secara umum kegiatan ini berlangsung dengan cukup baik mulai dari tahap awal sampai akhir kegiatan. Tujuan kegiatan seperti yang tercantum pada sebelumnya juga dapat tercapai. Hal ini ditandai dengan meningkatnya pengetahuan dan motivasi masyarakat untuk mencoba menerapkan konsep RPL di pekarangan rumahnya. Kegiatan ini diharapkan dapat terus berjalan terutama dapat dilanjutkan oleh pihak desa terutama Ibu-Ibu PKK. 


\section{Ucapan Terima Kasih}

Terima kasih sebesar besarnya kami ucapkan kepada seluruh pihak yang telah membantu dalam menjalankan kegiatan pengabdian kepada masyarakat ini, diantaranya: (1) masyarakat Desa Montong Betok atas kerjasama dan partisipasinya dalam pelaksanaan kegiatan ini, (2) LPPM Unram yang telah memfasilitasi pelaksanaan kegianatan KKN mahasiswa Universitas Mataram

\section{Daftar Pustaka}

Badan Litbang Pertanian. 2019. Kawasan Rumah Pangan Lestari. Kementrian Pertanian Republik Indonesia. http://www.litbang.pertanian.go.id/krpl/

Balai Penelitian dan Pengkajian Pertanian (BPTP)

Sulawesi Barat. 2020. Teknologi Vertikultur Sebagai Solusi Bertani Dilahan

Sempit. Kementrian Pertanian Republik Indonesia.

http://sulbar.litbang.pertanian.go.id/ind/ind

ex.php/info-teknologi/367-teknologi-

vertikultur-sebagai-solusi-bertani-dilahan$\underline{\text { sempit }}$

Balai Penelitian Tanaman Sayuran (BALITSA). 2020. Hydroponik solusi Pertanian Lahan Sempit. Badan Penelitian dan Pengembangan Pertanian, Kementrian Pertanian Republik Indonesia. http://balitsa.litbang.pertanian.go.id/ind/ind ex.php/berita-terbaru/581-hidroponiksolusi-pertanian-lahan-sempit

Nurwati, N., Surtinah, dan Masykur, A. (2015). Analisis Pemanfaatan Pekarangan Untuk Mendukung Ketahanan Pangan di Kecamatan Rumbai Pesisir Kota Pekan Baru. Jurnal Ilmiah Pertanian, 11(2), 1-8. 